\title{
Can Readability of Loan Description Affect Loan Success Rate and Loan Cost?: A Textual Analysis of P2P Loan Description
}

\author{
Haitao Si ${ }^{1}$, Siqi Jiang ${ }^{2}$, Yizhuo Fang ${ }^{3, *}$, Muhammad Usman ${ }^{4}$ \\ ${ }^{1}$ School of Finance, Zhongnan University of Economics and Law \\ 182\# Nanhu Avenue, East Lake High-tech Development Zone, Wuhan 430073, China \\ E-mail.sht_finance@foxmail.com \\ ${ }^{2}$ Faculty of Business and Economics, The University of Hong Kong \\ Pokfulam Road, Hong Kong 999077, China \\ E-mail.1155115546@link.cuhk.edu.hk \\ ${ }^{3}$ School of Finance, Xinjiang University of Finance \& Economics \\ No. 449 Beijing Middle Road, New Urban District, Urumqi 830012, China \\ * Corresponding author \\ E-mail.13608671126@163.com
}

${ }^{4}$ Department of Economics and Business Administration, University of Education Lahore (Faisalabad Campus) College Road Samanabad Faisalabad, Pakistan

E-mail.usmanzuel@yahoo.com

cross $^{r e f}$ http://dx.doi.org/10.5755/j01.ee.31.3.25760

Text is an important form of information transfer. In a P2P (Peer-to-Peer) loan market with severe information asymmetry, loan descriptive information voluntarily written by a borrower may generate significant influence on investors' decisionmaking. As an important language feature, readability determines whether the audience can accurately identify textual contents. To discuss the influence of readability of loan description on borrowing behaviors, the data of a Chinese P2P lending platform Renrendai during 2013-2017 were used in this study. Readability index of loan description was constructed through the textual analysis method, followed by an empirical verification of the influences of readability of loan description on loan success rate and loan cost. Results indicate that the readability of loan description in China's $P 2 P$ loan market can generate incremental information, and the readability of loan description has evident nonlinear relations with loan success rate and loan interest rate. Moreover, the readability of loan description presents a "reverse $U$-shaped" relation with loan success rate and a "U-shaped" relation with loan interest rate. Demographic information (gender and educational background) of borrowers will not influence investors' feedback behaviors toward the readability of loan description. Conclusions provide empirical evidence for standardizing loan descriptive information on P2P lending platforms.

Keywords: P2P Lending; Loan Description; Readability; Textual Analysis.

\section{Introduction}

Banking, in common with other areas of finance, is often considered an amoral field focused purely on risk and return (Perez, Del Mar Garcia de los Salmones \& Liu, 2019), and it focuses on profit maximization (Ezeoha, Uche \& Ujunwa, 2020). Low-income groups are usually excluded from traditional financial services. On the one hand, borrowers lack favorable credit investigation report, proof of income, and proof of assets; hence, banks face a high risk of adverse selection. On the other hand, borrowers are short of effective mortgage-backed assets, so banks are also confronted with great moral risks (Y. Li, Gao \& Li, 2014). P2P lending platforms, which have emerged in recent years (Planuch-Prats \& Salvador-Valles, 2018), allow borrowers to bypass financial institutions to directly acquire unsecured loans from individual investors. Compared with traditional financial institutions, characterized by directness and dispersity (Mild, Waitz \& Wockl, 2015), P2P lending platforms can treat lenders more equally, reduce financial discrimination (Herzenstein, Andrews, Dholakia \& Lyandres, 2008), improve credit services (Balyuk, 2019), lower transaction costs (Hadji Misheva, Spelta \& Giudici, 2019), and elevate utilization efficiency of social funds (Duarte, Siegel \& Young, 2012). As a new form of decentralized Internet-based financial operation mode, P2P lending platforms have attracted extensive attention from all sectors of society since their creation and achieved rapid development. Until the end of 2019, the accumulative volume of transactions on Renrendai exceeded RMB 100 billion.

However, the P2P loan market is faced with serious information asymmetry problem, and this problem in the $\mathrm{P} 2 \mathrm{P}$ loan market is more prominent than that in the traditional financial market (Luo \& Lin, 2013; Luz Mouronte-Lopez, 2019). On the one hand, in consideration 
of data privacy, partial information, which is accepted and confirmed only by the platform management party, serves as the basis for the assessment of the credit rating of borrowers. Hence, investors cannot see comprehensive borrower information. On the other hand, as most P2P lending transactions are operated under anonymity, borrowers can conceal information adverse to themselves to elevate their chances of obtaining loans and lowering loan costs. Moreover, given that a security guarantee is not needed in P2P lending, borrowers may violate loan agreements, make late payments, and even run away. Information provided by P2P lending platforms is limited and usually insufficient for investors to properly assess whether borrowers are trustworthy and whether they can pay back loans. As a result, investors face high risks of adverse selection and moral risks (Cummins, Lynn, Mac an Bhaird \& Rosati, 2019). Hence, long-term development of P2P loan market, to a great extent, depends on market participants' abilities to reduce information asymmetry with the help of effective information (Ye \& Chen, 2017). For investors, more information allows them to comprehensively know their borrowers to make correct investment decisions. For borrowers, disclosing more effective information can attract investors to a certain degree and increase the loan success rate (Chen, Huang \& Shaban, 2020). Information disclosed by borrowers can be divided into hard information and soft information (Iyer, Khwaja, Luttmer \& Shue, 2016), which contribute to the establishment of trust relationship between lenders and borrowers (Sukmaningsih, 2018). Hard information refers to information that can be expressed by accurate hard indexes, for example, assets, income, and credit rating. Soft information refers to information that cannot be collected and processed by using standard methods, such as borrower appearance, social relations, and loan description. Under the circumstance that P2P lending platforms operate totally by relying on trust mechanism, public information is the only path for investors to evade risks. Therefore, probing into the influences of loan information of P2P lending platforms on loan success rate and loan cost will be of great practical significance for mitigating the information asymmetry between investors and borrowers, thus evading $\mathrm{P} 2 \mathrm{P}$ credit risks and perfecting the construction of $\mathrm{P} 2 \mathrm{P}$ lending platforms.

Substantial research on $\mathrm{P} 2 \mathrm{P}$ lending discussed how to apply soft and hard information to alleviate the information asymmetry in the process of lending. In hard information, scholars mainly pay attention to asset information and personal physical signs of borrowers. Asset information includes real estate, car property, and monthly wage income of borrowers, whereas personal physical signs include age, credit rating, educational background, and marital status of borrowers. As for soft information, the focus is on loan description, appearance, and social relations of borrowers, wherein loan description refers to loan information voluntarily written by borrowers, on the basis of which investors can make investment decisions (Nowak, Ross \& Yencha, 2018). Many scholars discussed the content level of loan description, for example, vocabulary type used in loan description, which is manifested by character figures (Herzenstein, Sonenshei \& Dholakia, 2011; Wang \& He, 2015). However, loan description itself is not verified by lending platforms; hence, it can be easily covered up or distorted. To further analyze the effect of loan description on information asymmetry, readability index was constructed in this study, and the influences of loan description on loan success rate and loan interest rate were analyzed from the perspective of difficulty level of text understanding.

Chinese P2P market developed rapidly after 2012, and there has been frequent thunderstorms after 2017. Therefore, Data from Renrendai P2P lending platform during 2013-2017 were used in this study to construct the readability index of loan description, and an empirical analysis of the influences of readability of loan description on loan success rate and loan cost was carried out. The remainder of this study is arranged as follows. Section 2 is a brief retrospective analysis of literature with regard to the influence of loan information on borrowing behaviors in $\mathrm{P} 2 \mathrm{P}$ lending platforms, along with a review on the progress and deficiencies of existing research. Section 3 introduces the data and variables used in this study and the modeling process. Section 4 is an empirical study through econometric models. Section 5 presents the main study results, and Section 6 draws the conclusions.

\section{Literature Review and Research Hypotheses}

\section{Readability of Loan Description with Loan success Rate and Loan Cost}

Many scholars have explored the influence of loan information on loan success rate and loan cost. First, in terms of hard information, the credit rating of borrowers is of great importance to loan success; the higher the credit rating is, the easier for borrowers to get loans (Klafft, 2008; Wang \& Liao, 2014). However, as credit rating is not the actual credit score, those with low credit scores tend to select "borrow money" on platforms, thus causing an adverse selection problem (Freedman \& Jin, 2008). In addition, debt to income ratio can remarkably influence investors' decision making, that is, the lower the debt to income ratio of a borrower, the easier for him/her to obtain a loan (Gavurova, Dujcak, Kovac \& Kotaskova, 2018). As for character features of borrowers, existing studies show that age discrimination exists on $\mathrm{P} 2 \mathrm{P}$ lending platforms; young people and the aged have difficulty in obtaining loans. Pope and Sydnor (2011) found that among borrowers who uploaded photos, those who looked partially old in photos did not easily pass loan applications. Moreover, young people were considered a high-risk and high-default-rate group; hence, they could hardly obtain loans (Gonzalez \& Loureiro, 2014). As a general rule, borrowers with higher education have high credit rating and low default risk, and it is easier for them to be favored by investors so as to get loans. However, empirical research works show that investors do not prefer well-educated people, meaning that borrowers have deviations in terms of identification risk of educational background (Liao, Ji \& Zhang, 2015). According Zhao and Qi (2019), occupational discrimination exists in China's P2P loan market, and the improvement of information disclosure quality could effectively relieve occupational discrimination. 
As for soft information, scholars pay attention to loan description, appearance, and social relations of borrowers. Most scholars focus on loan description of borrowers. Loan description is a self-statement voluntarily written by a borrower to persuade investors to make decisions. On the basis of hard information, these descriptive contents can further reduce information asymmetry between lenders and borrowers, thus influencing borrowing behaviors. First, loan description can lower loan costs (Peng, Zhao \& Zhou, 2016), and borrowers with low credit rating tended to provide loan descriptions (Wang and He, 2015; Li et al., 2014). Moreover, when a large number of characters are used in a loan description, the description is specific (Larrimore, L., Jiang, Larrimore, Markowitz \& Gorski, 2011), more vocabulary types are used (Herzenstein et al., 2011), and more optimistic vocabularies are used (El-Haj, Rayson, Walker, Young \& Simaki, 2019); thus, the loan interest rate will be lower and loan success rate will be higher. To analyze from the angle of character features embodied in such description, if a loan description expresses "diligent" and "trustworthy" character features or success stories, then the loan success rate will be higher (Wang and He, 2015). Furthermore, Pope and Sydnor (2011) found that borrowers who provide their personal photos enjoyed higher loan success rate. Scholars have found that good-looking borrowers (Ravina, 2008) and borrowers who seem trustworthy (Duarte, Siegel \& Young, 2012) can obtain loans more easily. Among research regarding social relations, a common viewpoint is that strong social relations can help elevate loan success rate and reduce the loan interest rate of borrowers. For instance, Berger and Gleisner (2009) found that especially for borrowers with low credit rating, joining a specific group could reduce information asymmetry, which could lower the loan interest rate while elevating loan success rate. Lin, Prabhala \& Viswanathan (2013) found that borrowers with many friends could obtain loans more easily, and the loan interest rate was low. In the research based on machine learning algorithm, Niu, Ren \& Li (2019) found that social network information could evidently improve the prediction accuracy of loan defaults.

However, among the research related to loan description, scholars have unfolded their discussion from the content level of loan description. As authenticity and reliability of loan description are not verified by platforms, borrowers do not have to bear any legal liability because "their words are not matched by deeds." As a result, a bidder can make wrong decisions due to a fictional loan description. Studying loan descriptions only from the content level is insufficient. In the field of news text analysis, readability is used to measure whether texts can be easily read, browsed, or understood (Huang, 2010). Covering up or distorting readability, which is an important language feature, is more difficult compared with contents. Many scholars have studied the text readability. For example, Bacha \& Ajina (2019) found that there is a significant positive relationship between CSR performance and the readability of the annual report; Hassan, Abu Abbas \& Garas (2019) found that firms with higher annual report readability are more profitable and have lower agency costs.
To a certain degree, readability measures ability, educational degree, and even financial status of an author (Rennekamp, 2012), and it is critical for investors' decision making. Among the previous research, El-Haj et al. (2015) and Chen, Ye \& Deng (2018) deemed that the readability of loan description presented a linear positive correlation with loan success rate, that is, the better the readability is, the higher the loan success rate is. Using the data from Prosper P2P lending platform, Peng et al. (2016) found that readability had a "reverse U-shaped" correlation with loan success rate, whereas it had a linear positive correlation with loan cost. Thus, the data from the Chinese P2P lending platform were used to further discuss this problem.

On the one hand, the simpler the contents in loan description, the easier that bidder can understand contents. Although texts with too high readability are vivid and easy to understand, they may have deficiencies in language precision and rigor of theory (Yan and Sun, 2002). Hence, they can not accurately express the intention of a borrower, and a borrower will have difficulty in winning the trust of a bidder so as to obtain the loan. In other words, when the readability of loan description is very high, a borrower may be faced with low loan success rate or high loan interest rate. On the other hand, human attention under a specific environment is limited. When people encounter a large quantity of information, they have to screen information for selective reading (Kahneman and Tversky, 1973), and when text contents are too hard to understand, they may give up reading (McKeown, Beck, Sinatra \& Loxterman, 1992). Furthermore, as Renrendai releases objects at fixed point and fixed time as stipulated, competitive relation exists among bidders. Therefore, when encountering objects with hard-to-understand loan description, bidders will spend more time in understanding contents in the loan description unavoidably, and they may miss many high-quality objects. From the angle of opportunity cost, relative to objects with hard-to-understand loan description, loan descriptions that can be understood easily can shorten the reading time of bidders. Hence, bidders can read more objects within the same time period and find higher-quality objects to achieve benefit maximization. Loan descriptions with low readability will create an adverse effect on bidders and cannot be recognized by bidders, which may reduce loan success rate and increase loan cost. On the basis of the above analysis, hypothesis $H 1$ is proposed:

H1: Readability of loan description has a reverse $U$ shaped relation with loan success rate and a $U$-shaped relation with loan interest rate.

\section{Readability of Loan Description with Heterogeneity of Loan Success Rate and Loan Cost}

Under information asymmetry, when investors fail to acquire sufficient verifiable information used to evaluate credit level and loan repayment ability of borrowers, all kinds of identity labels will generate a guiding effect on investment decision making of lenders (Peng \& Lin, 2018). Many scholars have investigated the relationships of demographic characteristics of borrowers with their loan success rate and loan cost, mainly in aspects of age, gender, race, and educational background. 
A consensus has nearly been reached over whether age discrimination exists in the P2P loan market, that is, young people and the aged usually have difficulty in obtaining loans. Pope and Sydnor (2011) found that among borrowers who uploaded photos, if they looked partially old in photos, then these loan applications could not easily be approved. Young people are regarded as a high-risk group with high default rate, thus explaining their difficulty in obtaining loans (Gonzalez \& Loureiro, 2014). No final conclusion has been made over whether age discrimination exists in the $\mathrm{P} 2 \mathrm{P}$ loan market, which may be influenced by social traditional culture of various countries. Duarte et al. (2012) found that although the expected return rate of investments on male borrowers was high, female borrowers could obtain loans more easily, indicating that male gender discrimination existed on American P2P lending platforms. Chen, Li \& Lai (2017) used the transaction data of a Chinese P2P lending platform PPDAI, and they found that female borrowers had low default rate, but they needed to pay a higher interest rate. Clearly, remarkable female gender discrimination existed in China's P2P loan market. In the aspect of racial discrimination, research on American P2P lending platforms indicate that African-Americans have more difficulty in obtaining loans than white people do (Pope \& Sydnor, 2011), and even if they obtain loans, they need to pay a higher interest rate (Ravina, 2008). However, the higher interest rate does not mean racial discrimination, because the default rate of African-Americans is higher, and the actual return rate of investments on AfricanAmericans is lower. As for educational background, scholars have inconsistent opinions. Sun and Fan (2016) found that the higher the educational degree of borrowers, the higher their loan success rate is. However, Liao et al. (2015) believed that investors did not prefer well-educated people, and lenders had deviations in the aspect of identification risk of educational background.

Although previous research have not reached any consensus over gender and educational background, they have pointed out that investors will take identity labels of borrowers into consideration when deciding whether to give funds to borrowers, and then different demographic characteristics will generate great differences in the aspect of credit evaluation of borrowers. On this basis, when accepting the readability of descriptive texts, investors may make a difference between loan descriptions provided by borrowers with different genders and educational backgrounds. In other words, demographic characteristics of borrowers will influence the action process of readability. On the basis of the above analysis, hypothesis $\mathrm{H} 2$ is put forward:

H2: Demographic characteristic information (gender and educational background) of borrowers will influence investors' feedback behaviors over the readability of loan descriptions.

\section{Data, Variables, and Methods}

\section{Sample Selection and Data Sources}

All data of individual borrowing demands on a famous Chinese P2P lending platform Renrendai from October 1,
2013 to November 30, 2017 were used in this study as initial samples. To control the influence of abnormal values in the samples, the sampled data were processed as follows: (1) samples where borrowers were loaded in Hong Kong, Macao, Taiwan, and China were excluded, and borrowers located in Shenzhen were included into Guangdong Province; (2) the influence of extreme age values was eliminated, and borrower ages were put under winsorization at a level fluctuating at $0.1 \%$; (3) the influence of extreme values of readability index was excluded, the readability of loan description was winsorized, and the final sample size was 952,237.

\section{Definition and Calculation of Main Variables}

\section{Loan success rate (Success)}

The variable is 1 when a borrower successfully obtains a loan; otherwise it is 0. Loan STATES of loan objects at time points of data collection were acquired via Python, and this variable was taken as the basis to judge loan success rate.

\section{Loan interest rate (Interest)}

It is the annual interest rate for a loan successfully obtained by a borrower, and it is used to measure loan cost of a borrower. The higher the loan interest rate is, the higher the loan cost; otherwise, the lower the loan cost.

\section{Readability of loan description (Easyread)}

By reference to the formula of text readability corrected by Huang (2010), the readability of a borrower's loan description was calculated as shown in mode (1):

$$
Y=0.8 \times \mathrm{X}_{1}+X_{2}
$$

where $Y$ is readability score; $X_{l}$ is average number of characters in each phrase, namely the ratio of total characters in loan description to number of commonly used punctuation marks, which include period, comma, colon, semicolon, dash, exclamation mark, and question mark. To prevent a borrower from mistakenly using English punctuation marks as Chinese ones when inputting loan description, the English period, comma, exclamation mark, and question mark are hereby added. $X_{2}$ is percentage of hard characters, namely the percentage of characters beyond 5,708 common modern Chinese characters (Chen et al., 2018) in a total number of characters in loan description. When the number of characters in each phrase of loan description or percentage of hard characters increases, it will influence the lender's understanding of the loan description. Therefore, the greater the $Y$ value, the poorer the readability of loan description is. However, after indexes were constructed, no punctuation marks were found in loan descriptions of a small number of borrowers, which would lead to the increase of readability index by a large margin, generate a large number of outliers and abnormal values, and influence regression results. Hence, winsorization was carried out in this study using winsor 2 command of Stata to eliminate the influence of abnormal values.

4. Control variablesBy the reference to the practice of Michels (2012) and Chen et al. (2018), three variable types - order factor, individual factor, and macro factor- of basic information of borrowers were controlled in the study of the influence of readability of loan description on loan 
success rate and loan cost, and specifically, order factors included: loan term (Months) and loan amount (Amount); individual factors included borrower age (Age), marital status (Married), income (Income), educational background (Education), owning a house or not (House), and owning a car or not (Car), worktime (Worktime); macro factors included years of loan (Year) and region where the borrower is located (Region). As Renrendai set seven income intervals for borrowers to describe their monthly income, specifically, lower than 1,000, 1,001-2,000, 2,001-5,000, 5,001-1,0000, 10,001-20,000, 20,001-50,000, and higher than 50,000, classified variable Income was used to measure income level of borrower, and the value range was 1-7. The greater the numerical value, the higher the income level. Marital status included married, unmarried, divorced, and widowed. Because widowed and divorced represent unstable marital status and may affect the ability to repay, in this study, when marital status is married, the value of Married is 1 ; otherwise it is 0 . Table 1 provides a list of the specific variable definitions.

Table 1

Definition of Variables

\begin{tabular}{|c|l|}
\hline Variable & \multicolumn{1}{|c|}{ Definition } \\
\hline Success & 1 when the loan is successful, 0 otherwise \\
\hline Interest & $\begin{array}{l}\text { The borrower's interest rate, the higher the interest rate, the } \\
\text { greater the cost of borrowing }\end{array}$ \\
\hline EasyRead & $\begin{array}{l}\text { l.8 (total number of characters in loan description / number of } \\
\text { common punctuation marks) + (number of uncommonly used } \\
\text { Chinese characters / total number of characters in loan } \\
\text { description) }\end{array}$ \\
\hline Amount & Natural logarithm of total borrowings \\
\hline Months & Borrower term \\
\hline House & 1 if the borrower owns the property, otherwise 0 \\
\hline Car & 1 if the borrower owns the car, otherwise 0 \\
\hline Education & $\begin{array}{l}\text { High school or below, junior college, undergraduate, graduate } \\
\text { students take 1,2,3,4 respectively }\end{array}$ \\
\hline Worktime & $\begin{array}{l}\text { Values less than 1 year, 1-3 years, 3-5 years, and more than 5 } \\
\text { years are 1,2,3,4 }\end{array}$ \\
\hline Income & $\begin{array}{l}\text { Borrower's income level, value 1-7, the greater the value, the } \\
\text { higher the income level }\end{array}$ \\
\hline Married & Married as 1, unmarried as 0 \\
\hline Age & Borrower's age \\
\hline Year & Year the borrower borrowed \\
\hline Region & Province where the borrower is located \\
\hline
\end{tabular}

\section{Modeling}

On the basis of the research by Klafft (2008) and Michels (2012), model (2) was used to verify the nonlinear influence of readability of loan description on loan success rate and loan cost by combining the research objectives.

$$
Y=\beta_{0}+\beta_{1} X+\beta_{2} X^{2}+\beta_{3} \text { Control }+\varepsilon
$$

The explained variables $Y$ in model (2) are loan success rate (Success) and loan cost (Interest). When the loan is successfully obtained, the value of Success is 1 ; otherwise it is 0 . Interest is loan interest rate of borrower, in which the higher the interest rate is, the higher the loan cost is. Logit and OLS regression models were employed in this study to explore the influence of readability on loan success rate and loan cost. $X$ is an explanatory variable, namely readability of loan description (EasyRead), where $X^{2}$ is its quadratic term, and its calculation formula is: readability $=0.8 *$ (total number of characters in loan description / number of common punctuation marks) + (number of uncommonly used Chinese characters / total number of characters in loan description), and the greater the value of EasyRead, the poorer the readability is. If the readability of loan description has a "reverse U-shaped" relation with loan cost, then the quadratic term should be negative, namely $\beta_{1}<0$. If the readability of loan description presents a "U-shaped" relation with loan cost, then the quadratic term should be positive, namely $\beta_{l}>0$. Control is the control variable selected in this study. On the basis of the research results regarding the influence factors of $\mathrm{P} 2 \mathrm{P}$ borrowing behaviors in the existing literature.

\section{Result Analysis}

\section{Descriptive Statistics}

Table 2 shows the descriptive statistical results of the variables. Average loan success rate, average loan interest rate, and maximum loan interest rate are $56.2 \%, 11.7 \%$, and $24 \%$, respectively, where the maximum loan interest rate does not exceed the nationally stipulated highest interest rate (4 times of the basic interest rate of Central Bank). Average loan amount is RMB 69,878; hence, petty loans mainly comprise the $\mathrm{P} 2 \mathrm{P}$ loan market. The maximum amount is RMB 1,000,000, which exceeds the stipulated limiting value in Interim Measures for the Administration of the Business Activities of Online Lending Information Intermediary Institutions. The amount of funds raised by the same natural person on the same P2P lending platform shall not exceed RMB 200,000. The average age of borrowers is less than 34 years old and their average years of working are approximately 2 years, indicating that most fund borrowers are young people who have taken jobs for not a long time. Moreover, $54.1 \%$ of borrowers are married, $39.3 \%$ own houses, and $21.7 \%$ own cars. The average readability of loan description is 7.35. According to the findings of Huang (2010), the readability of loan description in P2P lending platforms is generally strong.

Table 2

\section{Descriptive Statistics}

\begin{tabular}{|c|c|c|c|c|c|}
\hline Variables & Mean & Median & Min & Max & Obs \\
\hline Success & 0.562 & 0.496 & 0 & 1 & 952237 \\
\hline Interest & 11.661 & 2.186 & 7 & 24 & 952237 \\
\hline EasyRead & 7.350 & 1.700 & 0.246 & 14.400 & 952237 \\
\hline Months & 25 & 11.500 & 3 & 48 & 952237 \\
\hline Amount & 69878 & 70736 & 1000 & 1000000 & 952237 \\
\hline Age & 33.425 & 7.927 & 20 & 59 & 950413 \\
\hline House & 0.393 & 0.489 & 0 & 1 & 952237 \\
\hline Car & 0.217 & 0.412 & 0 & 1 & 952237 \\
\hline Worktime & 2.360 & 1.127 & 1 & 4 & 784607 \\
\hline Married & 0.541 & 0.498 & 0 & 1 & 919170 \\
\hline Education & 2.124 & 0.776 & 1 & 4 & 877443 \\
\hline Income & 4.329 & 1.218 & 1 & 7 & 816491 \\
\hline
\end{tabular}


Haitao Si, Siqi Jiang, Yizhuo Fang, Muhammad Usman. Can Readability of Loan Description Affect Loan Success Rate...

\section{Influences of Readability of Loan Description on Loan Success Rate and Loan Cost}

The influences of readability on loan success rate and loan cost were investigated via Probit and OLS regression models. Table 3 shows the regression results, where columns (1) and (2) display the regression results of readability and loan success rate before and after control variables were added. Linear coefficient and quadratic term of readability (EasyRead) are significant at the $1 \%$ level in both models, linear coefficient is positive, and quadratic coefficient is negative, indicating that readability of loan description has a significant "reverse U-shaped" relation with loan success rate. Readability that is too high or too low will discourage investors from thoroughly understanding a borrower on the basis of loan description and will increase the difficulty for a borrower to obtain the loan. Only when readability is within a suitable scope can loan descriptions remarkably elevate loan success rate of a borrower, which is similar to the research conclusion of Peng et al. (2016). Columns (3) and (4) present the regression results of readability and loan cost before and after control variables are added. Linear coefficient and quadratic coefficient of readability index (EasyRead) are significant at the $1 \%$ level in both models, linear coefficient is negative, and quadratic coefficient is positive. Thus, readability of loan description presents a significant "U-shaped" relation with loan cost, and a moderate readability level helps a borrower convey his/her own idea and intention to investors and enhances investors' trust in the borrower to reach the goal of reducing loan cost. This finding is not consistent with the research conclusion drawn by Peng et al. (2016), who used credit data on American Prosper P2P lending platform, and they believed that loan interest rate only presented a linear positive correlation with readability. This finding indicates that $\mathrm{P} 2 \mathrm{P}$ credit markets in China and the US present different characteristics in terms of the relationship between readability of loan description and loan interest rate.

Table 3

Impact of Borrowing Description on Borrowing Success Rate and Borrowing Costs

\begin{tabular}{|c|c|c|c|c|}
\hline \multirow{2}{*}{ Variables } & $(1)$ & $(2)$ & $(3)$ & $(4)$ \\
\cline { 2 - 5 } & Success & Success & Interest & Interest \\
\hline \multirow{2}{*}{ EasyRead } & $3.925^{* * *}$ & $\begin{array}{c}2.335^{* * *} \\
(0.033)\end{array}$ & $\begin{array}{c}-0.272^{* * *} \\
(0.006)\end{array}$ & $\begin{array}{c}-0.428^{* * *} \\
(0.008)\end{array}$ \\
\hline \multirow{2}{*}{ EasyRead_sq } & $-0.242^{* * *}$ & $-0.142^{* * *}$ & $0.0155^{* * *}$ & $0.0245^{* * *}$ \\
& $(0.002)$ & $(0.002)$ & $(0.000)$ & $(0.001)$ \\
\hline \multirow{2}{*}{ Months } & & $0.113^{* * *}$ & & $0.0263^{* * *}$ \\
& & $(0.001)$ & & $(0.000)$ \\
\hline \multirow{2}{*}{ Age } & & $0.111^{* * *}$ & & $-0.0198^{* * *}$ \\
& & $(0.001)$ & & $(0.000)$ \\
\hline \multirow{2}{*}{ House } & & $-0.132^{* * *}$ & & $-0.0171^{* * *}$ \\
& & $(0.010)$ & & $(0.004)$ \\
\hline \multirow{2}{*}{ Car } & & $0.0390^{* * * *}$ & & $-0.131^{* * *}$ \\
& & $(0.011)$ & & $(0.004)$ \\
\hline \multirow{2}{*}{ Worktime } & & $-1.103^{* * *}$ & & $0.173^{* * *}$ \\
& & $(0.006)$ & & $(0.002)$ \\
\hline \multirow{2}{*}{ Amount } & & $-0.667^{* * *}$ & & $0.0707^{* * *}$ \\
& & $(0.006)$ & & $(0.003)$ \\
\hline \multirow{2}{*}{ Married } & & $0.595^{* * *}$ & & $-0.0851^{* * *}$ \\
& & $(0.010)$ & & $(0.004)$ \\
\hline \multirow{2}{*}{ Education } & & $0.459^{* * *}$ & & $-0.134^{* * *}$ \\
& & $(0.006)$ & & $(0.003)$ \\
\hline Income & & $0.438^{* * *}$ & & $-0.0470^{* * * *}$ \\
\hline
\end{tabular}

\begin{tabular}{|c|c|c|c|c|}
\hline \multirow{2}{*}{ Variables } & $(1)$ & $(2)$ & $(3)$ & $(4)$ \\
\cline { 2 - 5 } & Success & Success & Interest & Interest \\
\hline & & $(0.005)$ & & $(0.002)$ \\
\hline \multirow{2}{*}{ cons } & $-21.46^{* * *}$ & $-11.09^{* * * *}$ & $16.37^{* * *}$ & $16.84^{* * * *}$ \\
& $(0.141)$ & $(0.191)$ & $(0.031)$ & $(0.077)$ \\
\hline Year FE & Yes & Yes & Yes & Yes \\
\hline Prov FE & Yes & Yes & Yes & Yes \\
\hline$N$ & 952237 & 782158 & 952237 & 782158 \\
\hline adj. $R^{2}$ & & & 0.491 & 0.533 \\
\hline pseudo $R^{2}$ & 0.648 & 0.712 & & \\
\hline
\end{tabular}

Note: Standard error is in parentheses, $* * * p<0.01, * * p<0.05, * p<0.1$

\section{Heterogeneity Analysis of Demographic Information of Borrowers}

\section{Heterogeneity analysis of genders}

Previous research indicates that in Chinese and foreign P2P credit markets, gender discrimination exists among different degrees (Duarte et al., 2012; Chen et al., 2017), and when accepting readability of descriptive texts, investors may give differential treatments to loan descriptions provided by borrowers with different genders. Samples were divided into two groups (male group and female group) in this study for regression analysis. Table 4 shows the empirical results regarding the influences of readability of loan description on loan success rate and loan cost, classified by gender. Influences of loan description on loan success rate and loan cost presents no obvious different influences among borrowers of different genders. Therefore, unlike the findings that male gender discrimination or female gender discrimination exist in $\mathrm{P} 2 \mathrm{P}$ credit markets, the readability of loan description does not present evident gender characteristics and significant differences.

Table 4

Analysis of Gender Heterogeneity

\begin{tabular}{|c|c|c|c|c|}
\hline \multirow{2}{*}{ Variables } & \multicolumn{2}{|c|}{ Success } & \multicolumn{2}{|c|}{ Interest } \\
\hline & Male & Female & Male & Female \\
\hline EasyRead & $\begin{array}{l}2.148^{* * * *} \\
(0.029) \\
\end{array}$ & $\begin{array}{c}3.166^{* * *} \\
(0.078) \\
\end{array}$ & $\begin{array}{c}-0.378^{* * *} \\
(0.009) \\
\end{array}$ & $\begin{array}{c}-0.650^{* * *} \\
(0.021) \\
\end{array}$ \\
\hline EasyRead_sq & $\begin{array}{c}-0.131^{* * *} \\
(0.002)\end{array}$ & $\begin{array}{c}-0.191^{* * *} \\
(0.005)\end{array}$ & $\begin{array}{c}0.0217^{* * * *} \\
(0.001)\end{array}$ & $\begin{array}{c}0.0375^{* * *} \\
(0.001)\end{array}$ \\
\hline Months & $\begin{array}{l}0.110^{* * * *} \\
(0.001)\end{array}$ & $\begin{array}{l}0.121^{* * * *} \\
(0.002)\end{array}$ & $\begin{array}{c}0.0275^{* * *} \\
(0.000)\end{array}$ & $\begin{array}{c}0.0249^{* * * *} \\
(0.001)\end{array}$ \\
\hline Age & $\begin{array}{l}0.112^{* * * *} \\
(0.001)\end{array}$ & $\begin{array}{l}0.107^{* * * *} \\
(0.002)\end{array}$ & $\begin{array}{c}-0.0216^{* * * *} \\
(0.000)\end{array}$ & $\begin{array}{c}-0.0136^{* * * t} \\
(0.000)\end{array}$ \\
\hline House & $\begin{array}{c}-0.144^{* * *} \\
(0.011)\end{array}$ & $\begin{array}{c}-0.125^{* * *} \\
(0.025)\end{array}$ & $\begin{array}{c}-0.0174^{* * *} \\
(0.005)\end{array}$ & $\begin{array}{c}-0.00808 \\
(0.005)\end{array}$ \\
\hline Car & $\begin{array}{c}0.0784^{* * *} \\
(0.012)\end{array}$ & $\begin{array}{c}0.00682 \\
(0.029)\end{array}$ & $\begin{array}{c}-0.136^{* * *} \\
(0.005)\end{array}$ & $\begin{array}{c}-0.127^{* * *} \\
(0.006)\end{array}$ \\
\hline Worktime & $\begin{array}{c}-1.052^{* * *} \\
(0.007)\end{array}$ & $\begin{array}{c}-1.277^{* * * *} \\
(0.014)\end{array}$ & $\begin{array}{l}0.183^{* * *} \\
(0.002)\end{array}$ & $\begin{array}{l}0.127^{* * *} \\
(0.003)\end{array}$ \\
\hline Amount & $\begin{array}{c}-0.705^{* * *} \\
(0.007)\end{array}$ & $\begin{array}{c}-0.561^{* * *} \\
(0.017) \\
\end{array}$ & $\begin{array}{c}0.0753^{* * * *} \\
(0.004)\end{array}$ & $\begin{array}{c}0.0639^{* * * *} \\
(0.006)\end{array}$ \\
\hline Married & $\begin{array}{l}0.586^{* * * *} \\
(0.011)\end{array}$ & $\begin{array}{l}0.586^{* * * *} \\
(0.023)\end{array}$ & $\begin{array}{c}-0.103^{* * *} \\
(0.005)\end{array}$ & $\begin{array}{c}-0.0182^{* * *} \\
(0.005)\end{array}$ \\
\hline Education & $\begin{array}{c}0.447^{* * * *} \\
(0.007)\end{array}$ & $\begin{array}{c}0.507^{* * * *} \\
(0.016)\end{array}$ & $\begin{array}{c}-0.136^{* * *} \\
(0.003)\end{array}$ & $\begin{array}{c}-0.112^{* * *} \\
(0.004) \\
\end{array}$ \\
\hline Income & $\begin{array}{l}0.440^{* * * *} \\
(0.005)\end{array}$ & $\begin{array}{l}0.458^{* * * *} \\
(0.011)\end{array}$ & $\begin{array}{c}-0.0485^{* * *} \\
(0.002)\end{array}$ & $\begin{array}{c}-0.0436^{* * *} \\
(0.002)\end{array}$ \\
\hline _cons & $\begin{array}{c}-10.08^{* * *} \\
(0.203)\end{array}$ & $\begin{array}{c}-15.12^{* * *} \\
(0.536)\end{array}$ & $\begin{array}{l}16.72^{* * *} \\
(0.082)\end{array}$ & $\begin{array}{l}17.24^{* * * *} \\
(0.217)\end{array}$ \\
\hline Year FE & Yes & Yes & Yes & Yes \\
\hline Prov FE & Yes & Yes & Yes & Yes \\
\hline$N$ & 575494 & 206664 & 575494 & 206664 \\
\hline $\operatorname{adj.} R^{2}$ & & & 0.509 & 0.606 \\
\hline pseudo $R^{2}$ & 0.696 & 0.740 & & \\
\hline
\end{tabular}

Note: Standard error is in parentheses, $* * * p<0.01, * * p<0.05, * p<0.1$ 
2. Heterogeneity analysis of educational backgrounds

People who have higher education have stronger language ability than those who do not. When reading loan descriptions of well-educated borrowers, investors can acquire more borrower information and reduce information asymmetry. Moreover, well-educated people have stable sources of income and higher income level, and their selfdiscipline ability in repaying on schedule is stronger (Liao et al., 2015). Therefore, the well-educated group should have higher loan success rate and lower loan cost. Samples were divided into two groups: those with an undergraduate degree or above and those with an undergraduate degree or below, followed by a regression analysis of readability of loan description and loan success rate. Table 5 displays the empirical results regarding the influences of readability of loan description on loan success rate and loan cost among the two sample types classified by educational background. For borrowers with higher education and those with lower education, readability of loan description presents no obvious different influences on loan success rate and loan cost, and investors do not prefer well-educated people when making investment decisions, which is identical with the research conclusions of Liao et al. (2015) and Peng and Lin (2018).

Heterogeneity Analysis of Educational Backgrounds

\begin{tabular}{|c|c|c|c|c|}
\hline \multirow[b]{2}{*}{ Variables } & \multicolumn{2}{|c|}{ Success } & \multicolumn{2}{|c|}{ Interest } \\
\hline & $\begin{array}{c}\text { undergraduate degree or } \\
\text { above }\end{array}$ & $\begin{array}{c}\text { undergraduate degree } \\
\text { below }\end{array}$ & $\begin{array}{c}\text { undergraduate degree or } \\
\text { above }\end{array}$ & $\begin{array}{c}\text { undergraduate degree } \\
\text { below }\end{array}$ \\
\hline EasyRead & $\begin{array}{l}1.911^{* * *} \\
(0.045)\end{array}$ & $\begin{array}{l}2.523^{* * *} \\
(0.034)\end{array}$ & $\begin{array}{c}-0.506^{* * *} \\
(0.016)\end{array}$ & $\begin{array}{c}-0.391^{* * * *} \\
(0.010)\end{array}$ \\
\hline EasyRead_sq & $\begin{array}{c}-0.117^{* * * *} \\
(0.003)\end{array}$ & $\begin{array}{c}-0.153^{* * *} \\
(0.002)\end{array}$ & $\begin{array}{c}0.0298^{* * *} \\
(0.001)\end{array}$ & $\begin{array}{c}0.0223^{\text {*** }} \\
(0.001)\end{array}$ \\
\hline Months & $\begin{array}{l}0.114^{* * *} \\
(0.001)\end{array}$ & $\begin{array}{l}0.113^{\text {**** }} \\
(0.001)\end{array}$ & $\begin{array}{c}0.0252^{* * *} \\
(0.000)\end{array}$ & $\begin{array}{c}0.0255^{* * *} \\
(0.000)\end{array}$ \\
\hline Age & $\begin{array}{l}0.111^{\text {**** }} \\
(0.001)\end{array}$ & $\begin{array}{l}0.108^{\text {**** }} \\
(0.001)\end{array}$ & $\begin{array}{c}-0.0129^{* * *} \\
(0.000)\end{array}$ & $\begin{array}{c}-0.0222^{* * *} \\
(0.000)\end{array}$ \\
\hline House & $\begin{array}{r}-0.0111 \\
(0.019)\end{array}$ & $\begin{array}{c}-0.170^{* * * *} \\
(0.012)\end{array}$ & $\begin{array}{c}-0.0850^{* * * *} \\
(0.005)\end{array}$ & $\begin{array}{c}0.0458^{* * *} \\
(0.005)\end{array}$ \\
\hline Car & $\begin{array}{l}0.0273 \\
(0.021)\end{array}$ & $\begin{array}{l}0.0258 \\
(0.013)\end{array}$ & $\begin{array}{l}-0.147^{* * *} \\
(0.005)\end{array}$ & $\begin{array}{l}-0.0865^{* * * *} \\
(0.005)\end{array}$ \\
\hline Worktime & $\begin{array}{c}-0.830^{* * * *} \\
(0.009)\end{array}$ & $\begin{array}{c}-1.217^{* * *} \\
(0.008)\end{array}$ & $\begin{array}{l}0.103^{\text {**** }} \\
(0.002)\end{array}$ & $\begin{array}{c}0.204^{* * *} \\
(0.002)\end{array}$ \\
\hline Amount & $\begin{array}{c}-0.815^{\text {**** }} \\
(0.012)\end{array}$ & $\begin{array}{c}-0.588^{* * *} \\
(0.008)\end{array}$ & $\begin{array}{l}0.118^{* * * *} \\
(0.004)\end{array}$ & $\begin{array}{c}0.0316^{* * *} \\
(0.004)\end{array}$ \\
\hline Married & $\begin{array}{l}0.582^{\text {**** }} \\
(0.019)\end{array}$ & $\begin{array}{l}0.540^{\text {**** }} \\
(0.012)\end{array}$ & $\begin{array}{c}-0.00666 \\
(0.005)\end{array}$ & $\begin{array}{c}-0.142^{* * * *} \\
(0.005)\end{array}$ \\
\hline Income & $\begin{array}{l}0.399^{* * *} \\
(0.009)\end{array}$ & $\begin{array}{c}0.468^{* * * *} \\
(0.006)\end{array}$ & $\begin{array}{c}-0.0446^{* * *} \\
(0.002)\end{array}$ & $\begin{array}{c}-0.0464^{* * *} \\
(0.002)\end{array}$ \\
\hline _cons & $\begin{array}{c}-7.058^{* * *} \\
(0.318)\end{array}$ & $\begin{array}{c}-11.82^{\text {*** }} \\
(0.237)\end{array}$ & $\begin{array}{l}15.96^{* * *} \\
(0.152)\end{array}$ & $\begin{array}{l}17.01^{* * * *} \\
(0.090)\end{array}$ \\
\hline Year FE & Yes & Yes & Yes & Yes \\
\hline Prov FE & Yes & Yes & Yes & Yes \\
\hline$N$ & 277756 & 504776 & 277756 & 504776 \\
\hline $\operatorname{adj} . R^{2}$ & & & 0.613 & 0.477 \\
\hline pseudo $R^{2}$ & 0.729 & 0.692 & & \\
\hline
\end{tabular}

Note: Standard error is in parentheses, $* * * p<0.01, * * p<0.05, * p<0.1$

\section{Robust Test}

To guarantee the reliability of main empirical results in this study, the following stability test was carried out:

1. Substitution of explanatory variable or addition of control variables

A substitutional relation exists between text length and text readability (Miller, 2010), and this relation can be used to measure test readability (Loughran and McDonald, 2014). By reference to the research of Peng and Lin (2018) and Chen et al. (2018), text length (Length) was used to substitute readability index or taken as a control variable for a regression analysis again. Table 6 shows the empirical results, indicating that the regression result after substitution of readability index or addition of control variable is robust.
Robust Test 1

Table 6

\begin{tabular}{|c|c|c|c|c|}
\hline \multirow{2}{*}{ Variables } & \multicolumn{2}{|c|}{ Substitute readability } & \multicolumn{2}{|c|}{ Add control variable } \\
\hline & Success & Interest & Success & Interest \\
\hline EasyRead & & & $\begin{array}{l}1.483^{* * * *} \\
(0.030)\end{array}$ & $\begin{array}{c}-0.212^{* * *} \\
(0.009) \\
\end{array}$ \\
\hline EasyRead_sq & & & $\begin{array}{c}-0.099^{* * *} \\
(0.002)\end{array}$ & $\begin{array}{c}0.0131^{* * * *} \\
(0.001)\end{array}$ \\
\hline Length & $\begin{array}{c}0.0645^{* * *} \\
(0.000) \\
\end{array}$ & $\begin{array}{c}-0.0151^{* * *} \\
(0.000) \\
\end{array}$ & $\begin{array}{c}0.0243^{* * *} \\
(0.000)\end{array}$ & $\begin{array}{c}-0.0069^{* * *} \\
(0.000) \\
\end{array}$ \\
\hline Length_sq & $\begin{array}{c}-0.000161^{* * * *} \\
(0.000)\end{array}$ & $\begin{array}{c}0.0000308^{* * *} \\
(0.000)\end{array}$ & & \\
\hline Months & $\begin{array}{c}0.109^{* * *} \\
(0.001)\end{array}$ & $\begin{array}{c}0.0311^{* * * *} \\
(0.000)\end{array}$ & $\begin{array}{l}0.117^{* * * *} \\
(0.001)\end{array}$ & $\begin{array}{c}0.0283^{* * *} \\
(0.000)\end{array}$ \\
\hline Age & $\begin{array}{c}0.0944^{* * *} \\
(0.001)\end{array}$ & $\begin{array}{c}-0.0139^{* * *} \\
(0.000)\end{array}$ & $\begin{array}{c}0.0958^{* * * *} \\
(0.001)\end{array}$ & $\begin{array}{c}-0.0149^{* * * *} \\
(0.000) \\
\end{array}$ \\
\hline House & $\begin{array}{c}0.0327^{* *} \\
(0.011) \\
\end{array}$ & $\begin{array}{c}-0.0321^{* * *} \\
(0.004) \\
\end{array}$ & $\begin{array}{c}0.0936^{* * * *} \\
(0.011)\end{array}$ & $\begin{array}{c}-0.0496^{* * *} \\
(0.004) \\
\end{array}$ \\
\hline Car & $\begin{array}{c}0.137^{* * *} \\
(0.013) \\
\end{array}$ & $\begin{array}{c}-0.126^{* * *} \\
(0.004)\end{array}$ & $\begin{array}{l}0.207^{* * *} \\
(0.012) \\
\end{array}$ & $\begin{array}{c}-0.144^{* * *} \\
(0.004) \\
\end{array}$ \\
\hline Worktime & $\begin{array}{c}-0.876^{* * *} \\
(0.006) \\
\end{array}$ & $\begin{array}{c}0.118^{* * * *} \\
(0.002)\end{array}$ & $\begin{array}{c}-0.972^{* * *} \\
(0.006)\end{array}$ & $\begin{array}{c}0.136^{* * *} \\
(0.002) \\
\end{array}$ \\
\hline Amount & $\begin{array}{c}-0.941^{* * * *} \\
(0.007)\end{array}$ & $\begin{array}{c}0.0787^{* * *} \\
(0.003)\end{array}$ & $\begin{array}{c}-0.883^{* * *} \\
(0.007)\end{array}$ & $\begin{array}{c}0.0764^{* * *} \\
(0.003)\end{array}$ \\
\hline
\end{tabular}


Haitao Si, Siqi Jiang, Yizhuo Fang, Muhammad Usman. Can Readability of Loan Description Affect Loan Success Rate...

\begin{tabular}{|c|c|c|c|c|}
\hline \multirow{2}{*}{ Variables } & \multicolumn{2}{|c|}{ Substitute readability } & \multicolumn{2}{c|}{ Add control variable } \\
\cline { 2 - 5 } & Success & Interest & Success & Interest \\
\hline \multirow{2}{*}{ Married } & $0.516^{* * *}$ & $-0.0619^{* * *}$ & $0.490^{* * *}$ & $-0.0605^{* * *}$ \\
& $(0.011)$ & $(0.004)$ & $(0.011)$ & $(0.004)$ \\
\hline \multirow{2}{*}{ Education } & $0.426^{* * *}$ & $-0.108^{* * *}$ & $0.402^{* * *}$ & $-0.112^{* * *}$ \\
& $(0.007)$ & $(0.003)$ & $(0.007)$ & $(0.003)$ \\
\hline \multirow{2}{*}{ Income } & $0.369^{* * *}$ & $-0.0220^{* * *}$ & $0.373^{* * *}$ & $-0.0228^{* * *}$ \\
& $(0.005)$ & $(0.002)$ & $(0.005)$ & $(0.002)$ \\
\hline \multirow{2}{*}{ _cons } & $-1.881^{* * *}$ & $15.37^{* * *}$ & $-6.040^{* * *}$ & $15.96^{* * *}$ \\
& $(0.184)$ & $(0.070)$ & $(0.206)$ & $(0.077)$ \\
\hline time_effect & Yes & Yes & Yes & Yes \\
\hline prov_effect & Yes & Yes & Yes & Yes \\
\hline$N$ & 782158 & 782158 & 782158 & 782158 \\
\hline adj. $R^{2}$ & & 0.548 & & 0.546 \\
\hline pseudo $R^{2}$ & 0.768 & & 0.755 & \\
\hline
\end{tabular}

Note: Standard error is in parentheses, *** $p<0.01, * * p<0.05, * p<0.1$

\section{Resampling method}

According to stipulations specified in Interim Measures for the Administration of the Business Activities of Online Lending Information Intermediary Institutions, the amount of funds raised by the same natural person on the same P2P lending platform shall not exceed RMB 200,000. By reference to Chen et al. (2018), samples with loan amounts exceeding RMB 200,000 were excluded for a regression analysis again. The results indicated that after the samples were re-selected, the regression results showed no significant difference. The influence coefficients of readability on loan success rate and loan cost are significant at the $1 \%$ level, and the marks are identical with the results in Table 3.

Table 7

Robust Test 2

\begin{tabular}{|c|c|c|}
\hline \multirow{2}{*}{ Variables } & (1) & (2) \\
\hline & Success & Interest \\
\hline EasyRead & $\begin{array}{c}2.263^{* * *} \\
(0.027) \\
\end{array}$ & $\begin{array}{c}-0.436^{* * *} \\
(0.009)\end{array}$ \\
\hline EasyRead_sq & $\begin{array}{c}-0.137^{* * *} \\
(0.002)\end{array}$ & $\begin{array}{c}0.0249^{* * * *} \\
(0.001)\end{array}$ \\
\hline Months & $\begin{array}{c}0.105^{* * *} \\
(0.001)\end{array}$ & $\begin{array}{c}0.0289^{* * * *} \\
(0.000)\end{array}$ \\
\hline Age & $\begin{array}{c}0.110^{* * * *} \\
(0.001)\end{array}$ & $\begin{array}{c}-0.0198^{* * *} \\
(0.000)\end{array}$ \\
\hline House & $\begin{array}{c}-0.107^{* * *} \\
(0.010)\end{array}$ & $\begin{array}{c}-0.0172^{* * *} \\
(0.004)\end{array}$ \\
\hline Car & $\begin{array}{c}0.0904^{\text {**** }} \\
(0.012)\end{array}$ & $\begin{array}{c}-0.130^{\text {**** }} \\
(0.004)\end{array}$ \\
\hline Worktime & $\begin{array}{c}-1.070^{* * * *} \\
(0.006)\end{array}$ & $\begin{array}{c}0.169^{* * * *} \\
(0.002)\end{array}$ \\
\hline Amount & $\begin{array}{c}-0.460^{\text {**** }} \\
(0.007)\end{array}$ & $\begin{array}{c}0.0227^{\text {**** }} \\
(0.003)\end{array}$ \\
\hline Married & $\begin{array}{c}0.564^{* * * *} \\
(0.010)\end{array}$ & $\begin{array}{c}-0.0777^{* * * *} \\
(0.004)\end{array}$ \\
\hline Education & $\begin{array}{c}0.453^{* * *} \\
(0.007)\end{array}$ & $\begin{array}{c}-0.130^{* * *} \\
(0.003)\end{array}$ \\
\hline Income & $\begin{array}{c}0.462^{* * *} \\
(0.005)\end{array}$ & $\begin{array}{c}-0.0572^{* * *} \\
(0.002)\end{array}$ \\
\hline _cons & $\begin{array}{c}-12.79^{* * * *} \\
(0.194)\end{array}$ & $\begin{array}{c}17.27^{\text {**** }} \\
(0.079)\end{array}$ \\
\hline Year FE & Yes & Yes \\
\hline Prov FE & Yes & Yes \\
\hline$N$ & 752402 & 752402 \\
\hline adj. $R^{2}$ & & 0.535 \\
\hline pseudo $R^{2}$ & 0.708 & \\
\hline
\end{tabular}

Note: Standard error is in parentheses, *** $p<0.01, * * p<0.05, * p<0.1$

\section{Change of regression model}

Logit binary model was used in the previous part to carry out regression analysis regarding the correlation between readability of loan description and loan success rate. In the stability test, Probit and Tobit models were reused for regression as shown in Table 8.

Table 8

Robust Test 3

\begin{tabular}{|c|c|c|}
\hline \multirow{2}{*}{ Variables } & Probit & Tobit \\
\hline & Success & Success \\
\hline EasyRead & $\begin{array}{l}1.052^{* * *} \\
(0.013)\end{array}$ & $\begin{array}{c}0.237^{* * *} \\
(0.001)\end{array}$ \\
\hline EasyRead_sq & $\begin{array}{c}-0.0634^{* * *} \\
(0.001)\end{array}$ & $\begin{array}{c}-0.0139^{* * *} \\
(0.000)\end{array}$ \\
\hline Months & $\begin{array}{c}0.0616^{* * *} \\
(0.000)\end{array}$ & $\begin{array}{c}0.0125^{\text {*** }} \\
(0.000)\end{array}$ \\
\hline Age & $\begin{array}{c}0.0616^{* * *} \\
(0.000)\end{array}$ & $\begin{array}{c}0.00994^{\text {*** }} \\
(0.000)\end{array}$ \\
\hline House & $\begin{array}{c}-0.0347^{* * *} \\
(0.006)\end{array}$ & $\begin{array}{c}0.0174^{* * *} \\
(0.001)\end{array}$ \\
\hline Car & $\begin{array}{c}0.0493^{* * * *} \\
(0.006)\end{array}$ & $\begin{array}{c}0.0302^{* * * *} \\
(0.001)\end{array}$ \\
\hline Worktime & $\begin{array}{c}-0.585^{* * *} \\
(0.003)\end{array}$ & $\begin{array}{c}-0.106^{* * * *} \\
(0.000)\end{array}$ \\
\hline Amount & $\begin{array}{c}-0.393^{* * *} \\
(0.003)\end{array}$ & $\begin{array}{c}-0.0504^{* * * *} \\
(0.000)\end{array}$ \\
\hline Married & $\begin{array}{l}0.328^{* * * *} \\
(0.006)\end{array}$ & $\begin{array}{c}0.0400^{* * * *} \\
(0.001)\end{array}$ \\
\hline Education & $\begin{array}{c}0.263^{\text {**** }} \\
(0.004)\end{array}$ & $\begin{array}{c}0.0442^{* * * *} \\
(0.000)\end{array}$ \\
\hline Income & $\begin{array}{l}0.240^{* * * *} \\
(0.003)\end{array}$ & $\begin{array}{c}0.0231^{* * * *} \\
(0.000)\end{array}$ \\
\hline _cons & $\begin{array}{c}-4.938^{* * * *} \\
(0.094)\end{array}$ & $\begin{array}{c}-0.758^{* * * *} \\
(0.009)\end{array}$ \\
\hline Year FE & Yes & Yes \\
\hline Prov FE & Yes & Yes \\
\hline$N$ & 782158 & 782158 \\
\hline pseudo $R^{2}$ & 0.702 & 0.798 \\
\hline
\end{tabular}

Note: Standard error is in parentheses, *** $p<0.01$, ** $p<0.05, * p<0.1$

\section{Endogenous problem}

As "learning effect" exists in loan description (Chen et al., 2018), that is, a borrower will use descriptions of loans successfully applied as reference when writing a loan description, and the biased error of this unmeasurable missing variable may result in endogenous problem of empirical results. If a borrower has "learning effect," then the borrower can imitate descriptions of successful loan objects to influence his/her own loan interest rate and loan success rate. Therefore, the above estimation results may have serious deviations. The construction method of instrumental variables by Chen et al. (2018) was used to construct instrumental variables according to peer effect. First, age cohorts were constructed (below 30, 31-40, 41-50, and over 51 years old). Per capita number of characters and per capita number of commonly used characters of the same type of borrowers who share the same age group, educational background, income level, and region (province) were calculated as instrumental variables of the readability index. The regression was carried out for loan success rate and loan interest rate via IV-Probit and 2SLS models.

After the "learning effect" of borrowers themselves was excluded, from the overall regression results, readability still had remarkable nonlinear correlations with loan success rate and loan interest rate, that is, readability had a "reverse U- 
shaped" relation with loan success rate and a "U-shaped" relation with loan interest rate.

Endogenous Problem

Table 9

\begin{tabular}{|c|c|c|}
\hline \multirow{2}{*}{ Variables } & (1) & (2) \\
\hline & Success & Interest \\
\hline EasyRead & $\begin{array}{c}8.970 * * * \\
(0.215)\end{array}$ & $\begin{array}{c}-5.548 \text { *** } \\
(0.341)\end{array}$ \\
\hline EasyRead_sq & $\begin{array}{c}-0.499 * * * \\
(0.014)\end{array}$ & $\begin{array}{c}0.321 * * * \\
(0.023)\end{array}$ \\
\hline Months & $\begin{array}{c}0.0198 * * * \\
(0.001)\end{array}$ & $\begin{array}{c}0.0580 * * * \\
(0.001)\end{array}$ \\
\hline Age & $\begin{array}{c}0.0310 * * * \\
(0.001)\end{array}$ & $\begin{array}{c}0.00108^{* * * *} \\
(0.000)\end{array}$ \\
\hline House & $\begin{array}{c}-0.0176 \\
(0.009)\end{array}$ & $\begin{array}{c}0.0515 * * * \\
(0.003)\end{array}$ \\
\hline Car & $\begin{array}{c}0.00208 \\
(0.010)\end{array}$ & $\begin{array}{c}-0.0142 * * \\
(0.005)\end{array}$ \\
\hline Worktime & $\begin{array}{c}-0.204 * * * \\
(0.011)\end{array}$ & $\begin{array}{c}-0.142 * * * \\
(0.006)\end{array}$ \\
\hline Amount & $\begin{array}{c}-0.487 * * * \\
(0.006)\end{array}$ & $\begin{array}{c}0.00380 \\
(0.006)\end{array}$ \\
\hline Married & $\begin{array}{c}0.295 * * * \\
(0.009)\end{array}$ & $\begin{array}{c}-0.00229 \\
(0.003)\end{array}$ \\
\hline Education & $\begin{array}{c}0.197 * * * \\
(0.008)\end{array}$ & $\begin{array}{c}-0.0426 * * * \\
(0.002)\end{array}$ \\
\hline Income & $\begin{array}{c}0.159 * * * \\
(0.004)\end{array}$ & $\begin{array}{c}-0.0482 * * * \\
(0.002)\end{array}$ \\
\hline _cons & $\begin{array}{c}-35.01 * * * \\
(0.774)\end{array}$ & $\begin{array}{c}35.59 * * * \\
(1.171)\end{array}$ \\
\hline Year FE & Yes & Yes \\
\hline Prov FE & Yes & Yes \\
\hline$N$ & 783125 & 511933 \\
\hline $\operatorname{adj} . R^{2}$ & & 0.520 \\
\hline
\end{tabular}

Note: Standard error is in parentheses, *** $p<0.01$, ** $p<0.05, * p<0.1$

\section{Discussion}

The empirical analysis results show that readability of loan description influences loan success rate and loan cost, and it presents significant nonlinear correlations with both. On the basis of this empirical result, a further discussion will be carried out, specifically as follows:

First, the principal regression results in Table 3 show that readability has a marked "reverse U-shaped" relation with loan success rate and a prominent "U-shaped" relation with loan cost. When readability is within a proper scope, on the one hand, an investor may gain a deeper understanding of a borrower, thus mitigating the difficulty for the borrower to obtain a loan. On the other hand, this helps a borrower convey his/her ideas and intention to an investor, thus enhancing the investor's trust in the borrower so as to reach the goal of reducing loan cost. Thus, Hypothesis Hl is verified, and the obtained correlation between readability and loan success rate is consistent with the research conclusion of Peng et al. (2016). However, when investigating the correlation between readability and loan cost using credit data on American P2P lending platform Prosper, Peng et al. (2016) found that loan interest rate had a linear positive correlation with readability, which is inconsistent with the conclusion in this study, manifesting that in Chinese and American P2P credit markets, readability exerts different influences on loan cost.

Second, Table 4 and Table 5 show that loan description generates obviously different effects on loan success rate and loan cost among borrowers of different genders and educational backgrounds. Hypothesis $H 2$ does not hold. In the heterogeneity analysis of educational backgrounds, the empirical result powerfully supports the research by Liao et al. (2015), namely borrowers of higher education have strong self-discipline abilities and low default rate. However, investors do not prefer welleducated people when making decisions, and they show deviations in the aspect of identifying credit risks through educational background. The possible reason is that on P2P lending platforms, a considerable proportion of investors are people of lower educational degree and they tend to treat borrowers of both higher education and lower education equally. Moreover, these investors will not distinguish between loan descriptions of borrowers due to their different educational backgrounds. Existing research indicate that men and women show different language expressions; women tend to express their emotions when expressing their ideas, whereas men pay more attention to the reliability of their own information (Award \& Ragowsky, 2008). Duarte et al. (2012) and Chen et al. (2017) found that gender discrimination existed in both American and Chinese P2P credit markets to a certain degree. Nevertheless, the empirical results in this study show that the readability of loan description does not generate remarkably different influences on loan success rate and loan cost among borrowers of different genders, possibly because when reading loan description, investors pay more attention to the description itself regardless of gender. Investors will not consider a loan description good simply because the borrower is male or bad because the borrower is female.

Thirdly, Table 6, 7, and 8 present the stability test of this study. The results in Table 6 show that when text length serves as the core explanatory variable and a substitutive index for readability, the loan success rate will first rise and then decline while loan cost will first decline and then rise with the increase of text length. This finding proves nonlinear correlations of readability with loan success rate and loan cost. In the meantime, when the explanatory variable remains unchanged, text length is added into the regression model as a control variable, and then the regression result will be convincing. Table 7 and Table 8 show the regression results after samples are changed and those after the regression model is changed, respectively, which verify the stability of the conclusions.

Fourth, if borrowers have "learning effect," then they can imitate descriptions of successful loan objects to influence their own loan interest rate and loan success rate (Chen et al., 2018). The biased error of this unmeasurable missing variable may result in endogenous problem of empirical results. Table 8 shows the fundamental regression results after "learning effect" is eliminated, and hypothesis $\mathrm{H} 1$ still holds. In the meantime, on the one hand, as well-educated people may have strong language expression abilities, they can convey more effective information to investors. On the other hand, well-educated people have relatively stable income and low default rate, so investors may prefer well-educated people when making decisions (Sun \& Fan, 2016). However, the regression results in Table 5 display that educational background does not influence investors' feedback behaviors over 
readability of loan descriptions, which is consistent with the research conclusion of Liao et al. (2015) and Peng and Lin (2018). Nevertheless, none of the previous literatures have considered the influence of "learning effect" on borrowing behaviors of borrowers of different educational backgrounds. In consideration of the "learning effect," this study pointed out that if borrowers imitated descriptions of successful loan objects, then loan description levels of borrowers of higher education and lower education may tend to be identical. Hence, the readability of loan description did not generate obviously different influences on loan success rate and loan cost among people of different educational backgrounds.

\section{Conclusion}

The P2P credit market has more prominent information asymmetry problem than the traditional financial market. Loan description provides borrowers with a channel to supplement their loan-related information and relieves this information asymmetry to a certain degree, so as to generate a significant influence on investors' decision making. Data from a P2P lending platform Renrendai during 2013-2017 were used in this study to construct the readability index of loan description, followed by an empirical study of correlations of readability of loan description with loan success rate and loan cost. The following research conclusions were drawn. First, the readability of loan description had a "reverse U-shaped" relation with loan success rate and a "U-shaped" relation with loan interest rate. Second, demographic information (gender and educational background) of borrowers would not influence investors' feedback behaviors over readability of loan description, that is, the readability of loan description would not generate significantly different influences on loan success rate and loan cost among borrowers of different genders and educational backgrounds.

To a great extent, long-term development of P2P credit market depends on market participants' abilities to use effective information to mitigate information asymmetry. Text contents have been investigated in detail by previous literatures, and literal expression form was supplemented in this study. The readability of loan description has been verified to generate incremental information in China's P2P credit market, thus providing an empirical evidence for standardizing descriptive loan information on P2P lending platforms. Of course, certain limitations exist in this study, mainly manifested by "biased error in selection" of samples. For instance, after loan applications are saturated, Renrendai will conduct a preview, which causes a certain "biased error in selection" of samples observed in this study. Although verification was implemented in this study by using a series of stability tests, better solutions in the follow-up research are necessary.

\section{References}

Bacha, S., \& Ajina, A. (2019). CSR performance and annual report readability: evidence from France. Corporate Governance: The International Journal of Business in Society, 20(2), 201-215. https://doi.org/10.1108/CG-02-20190060

Balyuk, T. (2019). Financial innovation and borrowers: Evidence from peer-to-peer lending. Rotman School of Management Working Paper No. 2802220. Available at SSRN: https://doi.org/10.2139/ssrn.2802220

Berger, S. C., \& Gleisner, F. (2009). Emergence of financial intermediaries in electronic markets: The case of online P2P lending. Business Research Journal, 2(1), 39-45. https://doi.org/10.1007/BF03343528

Chen, D., Li, X., \& Lai, F. (2017). Gender discrimination in online peer-to-peer credit lending: evidence from a lending platform in China. Electronic Commerce Research, 17(4), 553-583. https://doi.org/10.1007/s10660-016-9247-2

Chen, X., Huang, B., \& Shaban, M. (2020). Naive or sophisticated? information disclosure and investment decisions in peerto-peer lending. ADBI Working Paper, NO. 1069.

Chen, Y., Ye, D., \& Deng, J. (2018). Can readability of loan description promote lending success rate of online?. China Industrial Economics, (3), 174-192.

Cummins, M., Lynn, T., Mac an Bhaird, C., \& Rosati, P. (2019). Addressing information asymmetries in online peer-to-peer lending. In Disrupting Finance. Palgrave Studies in Digital Business \& Enabling Technologies. Palgrave Pivot, Cham. https://doi.org/10.1007/978-3-030-02330-0_2

Duarte, J., Siegel, S., \& Young, L.(2012). Trust and credit: the role of appearance in peer-to-peer lending. Review of Financial Studies, 25(8), 2455-2484. https://doi.org/10.1093/rfs/hhs071

El-Haj, M., Rayson, P., Walker, M., Young, S., \& Simaki, V. (2019). In search of meaning: Lessons, resources and next steps for computational analysis of financial discourse. Journal of Business Finance \& Accounting, 46(3/4), $265-306$. https://doi.org/10.1111/jbfa.12378

Ezeoha, A., Uche, C., \& Ujunwa, A. (2020). Crossing the borderline in strategic corporate philanthropy: Dangote and the construction of cement roads in Nigeria. Business Ethics: A European Review, 29(1), 70-81. https://doi.org/10. 1111/beer.12249

Freedman, S., \& Jin, G. Z. (2008). Do social networks solve information problems for peer-to-peer lending? Evidence from 
Prosper. com. NET Institute Working Paper No. 8-43, Available at SSRN: https://doi.org/10.2139/ssrn.1936057

Gavurova, B., Dujcak, M., Kovac, V., \& Kotaskova, A. (2018). Determinants of successful loan application at peer-to-peer lending market. Economics \& Sociology, 11(1), 85-99. https://doi.org/10.14254/2071-789X.2018/11-1/6

Gonzalez, L., \& Loureiro, Y. K. (2014). When can a photo increase credit? The impact of lender and borrower profiles on online peer-to-peer loans. Journal of Behavioral and Experimental Finance, 2, 44-58. https://doi.org/10. 1016/j.jbef.2014.04.002

Hadji Misheva, B., Spelta, A., \& Giudici, P. (2019). Network based scoring models to improve credit risk management in peer to peer lending platforms. Frontiers in Artificial Intelligence, 2, 3. https://doi.org/10.3389/frai.2019.00003

Hassan, M., Abu Abbas, B., \& Garas, S. (2019). Readability, governance and performance: a test of the obfuscation hypothesis in Qatari listed firms. Corporate Governance: The International Journal of Business in Society, 19(2), 270298. https://doi.org/10.1108/CG-05-2018-0182

Herzenstein, M., Andrews, R. L., Dholakia, U. M., \& Lyandres,E.(2008). The democratization of personal consumer loans? Determinants of success in online peer-to-peer lending communities. Bulletin of the University of Delaware, 15(3), 274-277

Herzenstein, M., Sonenshein, S., \& Dholakia, U. M. (2011). Tell me a good story and I may lend you money: The role of narratives in peer-to-peer lending decisions. Journal of Marketing Research, 48(SPL), 138-149. https://doi.org/10. 1509/jmkr.48.SPL.S138

Huang, M. (2010). A the characteristics of Chinese and the study of readability formula of Chinese news. Journalism \& Communication,18(4), 93-97.

Iyer, R., Khwaja, A. I., Luttmer, E. F., \& Shue, K. (2016). Screening peers softly: Inferring the quality of small borrowers. Management Science, 62(6), 1554-1577. https://doi.org/10.1287/mnsc.2015.2181

Kahneman, D., \& Tversky, A. (1973). On the psychology of prediction. Psychological Review, 80(4), 237-251. https://doi.org/10.1037/h0034747

Klafft, M. (2008). Peer to peer lending: auctioning microcredits over the internet. In Proceedings of the International Conference on Information Systems. Technology and Management. IMT, Dubai.

Larrimore, L., Jiang, L., Larrimore, J., Markowitz, D., \& Gorski, S. (2011). Peer to peer lending: The relationship between language features, trustworthiness, and persuasion success. Journal of Applied Communication Research, 39(1), 19-37. https://doi.org/10.1080/00909882.2010.536844

Li, Y., Gao, G., \& Li, Z. (2014). The influence of borrower's descriptive on investors' decision: Analyze based on P2P online lending. Economic Research Journal, (S1),145-157.

Liao, L., Ji, L., \& Zhang, W. (2015). Role of naratives in lending market: Evidence from P2P lending platform. Journal of Financial Research, (3),146-159.

Lin, M., Prabhala, N. R., \& Viswanathan, S. (2013). Judging borrowers by the company they keep: Friendship networks and information asymmetry in online peer-to-peer lending. Management Science, 59(1), 17-35. https://doi.org/10.1287/mnsc. 1120.1560

Loughran, T., \& McDonald, B. (2014). Measuring readability in financial disclosures. The Journal of Finance, 69(4), 16431671. https://doi.org/10.1111/jofi.12162

Luo, B., \& Lin, Z. (2013). A decision tree model for herd behavior and empirical evidence from the online P2P lending market. Information Systems and e-Business Management, 11(1), 141-160. https://doi.org/10.1007/s10257-011-0182-4

Luz Mouronte-Lopez, M. (2019). Improving business oversight in the information technology industry. Dyna, 94(3), 247247. https://doi.org/10.6036/9215

McKeown, M. G., Beck, I. L., Sinatra, G. M., \& Loxterman, J. A. (1992). The contribution of prior knowledge and coherent text to comprehension. Reading Research Quarterly, 27(1), 79-93. https://doi.org/10.2307/747834

Michels, J. (2012). Do unverifiable disclosures matter? Evidence from peer-to-peer lending. The Accounting Review, 87(4), 1385-1413. https://doi.org/10.2308/accr-50159

Mild, A., Waitz, M., \& Wockl, J. (2015). How low can you go?-Overcoming the inability of lenders to set proper interest rates on unsecured peer-to-peer lending markets. Journal of Business Research, 68(6), 1291-1305. https://doi.org/10.1016/j.jbusres.2014.11.021

Miller, B. P. (2010). The effects of reporting complexity on small and large investor trading. The Accounting Review, 85(6), 2107-2143. https://doi.org/10.2308/accr.00000001 
Haitao Si, Siqi Jiang, Yizhuo Fang, Muhammad Usman. Can Readability of Loan Description Affect Loan Success Rate...

Niu, B., Ren, J., \& Li, X. (2019). Credit scoring using machine learning by combing social network information: Evidence from peer-to-peer lending. Information, 10(12), 397. https://doi.org/10.3390/info10120397

Nowak, A., Ross, A., \& Yencha, C. (2018). Small business borrowing and peer-to-peer lending: Evidence from lending club. Contemporary Economic Policy, 36(2), 318-336. https://doi.org/10.1111/coep.12252

Peng, H., \& Lin, C. (2018). Arguments in Substances: are words useful in P2P lending?: Evidence from descriptions of loans in Renrendai.com. Journal of Financial Research, (11), 133-152.

Peng, H., Zhao, H., \& Zhou, Y. (2016). Could the loan description affect the loan cost and the loan success rate?: Textual analysis based on the loan description. Journal of Financial Research, (4), 158-173.

Perez, A., Del Mar Garcia de los Salmones, M., \& Liu, M. T. (2019). Maximising business returns to corporate social responsibility communication: An empirical test. Business Ethics: A European Review, 28(3), $275-289$. https://doi.org/10.1111/beer.12221

Planuch-Prats, C., \& Salvador-Valles, R. (2018). Digitalization and knowledge management in financial services. Dyna, 93(4), 356-356. https://doi.org/10.6036/8797

Pope, D. G., \& Sydnor, J. R. (2011). What's in a Picture? Evidence of Discrimination from Prosper.com. Journal of Human Resources, 46(1), 53-92. https://doi.org/10.1353/jhr.2011.0025

Ravina, E. (2008). Love \& loans: the effect of beauty and personal characteristics in credit markets. Available at SSRN: http://dx.doi.org/10.2139/ssrn.1107307. https://doi.org/10.2139/ssrn.1107307

Rennekamp, K. (2012). Processing fluency and investors' reactions to disclosure readability. Journal of Accounting Research, 50(5), 1319-1354. https://doi.org/10.1111/j.1475-679X.2012.00460.x

Sukmaningsih, D. W. (2018). A model for lender-borrower trust in peer-to-peer lending. ComTech: Computer. Mathematics and Engineering Applications, 9(1), 15-24. https://doi.org/10.21512/comtech.v9i1.4287

Sun, W. J., \& Fan, X. Y. (2016). Whether the experience and educational background can improve the success rate of loan? evidence from P2P platform. Journal of Central University of Finance \& Economics, (3), 33-41.

Wang, H., \& He, L. (2015). An empirical study of borrowing description's influence on P2P lending. Journal of Finance and Economics, 30(1), 77-85.

Wang, H., \& Liao, L. (2014). Chinese P2P platform's credit authentication mechanism research: Evidence from Renrendai. China Industrial Economics, (4), 136-147.

Yan, D., \& Sun, M. (2002). Study on the readability of share b's annual reports in the Shenzhen exchange. Accounting Research, (5), 10-17.

Ye, D., \& Chen, X. (2017). Is Punctuation and Word useful: Evidence from P2P Lending. Finance \& Trade Economics, (5), 65-79.

Zhao, L., \& Qi, R. (2019). Can improving the quality of information disclosure weaken the professional identity discrimination in the p2p lending market?. Transformations in Business \& Economics, 18(1), 214-233.

The article has been reviewed.

Received in April 2020; accepted in June 2020. 